\title{
HOW INDEPENDENT SCIENCE CAN CONTRIBUTE TO THE FIELD OF SOCIAL ENTREPRENEURSHIP IN SCANDINAVIA
}

\author{
Nadina Helen Bakos \\ ${ }^{1}$ Fil. Dr. Jan-U. Sandal Institute, Finstadjordet, Norway \\ e-mail:povost@janusandal.no
}

Received: 17 April 2021; Accepted: 29 April 2021 Published: 14 June 2021

\begin{abstract}
The purpose of the article is to suggest an analytical framework that shows how science can stimulate social entrepreneurship in the Scandinavian welfare states, and the difference between science and practice. The article relies on secondary source material, and is a work of synthesis and comparative science. The procedure has been to present thoughts and theories from outstanding scientists, authors and individuals who engage in topics related to entrepreneurship, innovation, social science and economic growth. The understanding of social entrepreneurship is built upon science on entrepreneurship in the European tradition. Because many different activities are called social entrepreneurship, this leads to a dilution of the concept. Innovation is free in thought and will, and it's the social entrepreneur that drives the innovation. Creativity is necessary for a successful innovation: the creative individual, creative process, creative environment and creative product. The entrepreneur's impact on the economy as a catalyst for growth and development of the society, is significant. We need independent international science and theories for social entrepreneurs to access independent information.
\end{abstract}

Keywords: Entrepreneurship in Scandinavia, social entrepreneurs, independent science, development of society, innovation, economic growth.

JEL classification: A13, D69, O10, O35

Citation:

Bakos, N.H (2021). How independent science can contribute to the field of social entrepreneurship in Scandinavia. Access to science, business, innovation in digital economy, ACCESS Press, 2(2): 192-202. https://doi.org/10.46656/access.2021.2.2(6)

\section{INTRODUCTION}

According to Joseph A. Schumpeter (1912), an entrepreneur is a creative leader who raises capital in order to spread new combinations of land and labour. It is the entrepreneur's effort through will and action that is essential for the success or lack of it. Capital can be used for means of production by the entrepreneur, but the process is not dependent on it. When using Schumpeter theory, a social entrepreneur is a creative leader who raises capital in order to spread new combinations of land and labour in a social system. A social entrepreneur's goal is to create a better world for the population. A social entrepreneur has never the role as a capitalist, an HR manager or a businessman. To be a social entrepreneur is not a profession, but a position that ends when a business is built and enters the static production function. 
Scandinavian countries are facing new challenges in the social sector. Due to the emerging start-ups, incubators and political incentives, the Scandinavian countries have an opportunity to embrace the entrepreneurial economy and reap the benefits created by social entrepreneurs. The static system of the governments cannot do the same as private individuals. The reality has been dominated by an overflow of literature as well as political programs postulating the natural right given by the political system to take the lead in innovation, business entrepreneurship and social entrepreneurship. Only lately - over the past two decades, scientifically based literature has played a significant role in the development sphere of social entrepreneurship and innovation management in the Scandinavian context. Overall access to knowledge, markets and capital in Scandinavia is controlled by the government. The need for science to reveal political propaganda is crucial. When the roots of science are brought into the picture, political propaganda always fails.

Articles and books that are cited in this article have been carefully chosen. The literature review is based on works by Jean-Baptiste Say, Frederick W. Taylor, Joseph A. Schumpeter, Bengt Johannisson, Peter Drucker, Jan-Urban Sandal, and J. Gregory Dees. Their comprehensive scientific work could benefit scholars and other actors in the field of social entrepreneurship.

\section{Materials and Methods}

This article aims to analyze social entrepreneurship, it's effects on the three countries Denmark, Norway and Sweden, and examine the scientific, political and practical approach to entrepreneurship and social entrepreneurship. The layout of this article is a research into social entrepreneurship, theories on economic development, economic science and research on social entrepreneurship. The article relies on secondary source material, and is a work of synthesis and comparative science. It is a study performed during The Reading Course RC-01-A at Fil. Dr. Jan-U. Sandal Institute.

This study is based on theories on innovation, economic development, entrepreneurship, democracy and the welfare state. The procedure has been to present thoughts and theories from outstanding scientists, authors and individuals. Studies related to social and political development, innovation management and social entrepreneurship have been examined.

The target groups for this article are academics, students and practitioners. Other likely groups are scientists and teachers in the field of innovation, entrepreneurship and economic development. The study may be useful for entrepreneurs and individuals who want to create new combinations of the first and second production function.

\section{Results}

The understanding of social entrepreneurship is built upon the science of entrepreneurship in the European tradition. Science describes a mentality and a behaviour that fits in all contexts about economic and social development. The understanding of social entrepreneurs is based upon a version of entrepreneurs (Sandal, 2008, p. 117). Richard Cantillon introduced the term entrepreneur to the field of economics in his text "Essai 
sur nature du commerce en général", published in 1755. Cantillon held that the entrepreneur played a social role in a financial system. He considered the entrepreneur to be a risk taker, a person who tries to balance supply and demand while he is bearing the risk.

Jean Baptiste-Say (1821) was convinced that the entrepreneur is an economic agent who unites the combination of land, labor and capital. He explained that the entrepreneur has the ability to bring to the market products that people need and want. Say also called the entrepreneur "the master agent". By being the master agent, the entrepreneur must have a combination of moral qualities. He has the knowledge of the world, the knowledge of business, knows the art of administration and he must give attention to order and economy. The entrepreneur shifts economic resources out of an area of lower and into an area of higher productivity and greater yield.

In the book "Teorie der wirtschaftlichen Entwicklung" from 1912, Joseph A. Schumpeter gave innovation a key explanation in economic development. He stated that innovation is initiated by a single entrepreneur. He is able to combine land and labour in a way that previously was not possible or not as efficient as before. His theories are still valid in present time because an entrepreneur must master the same skills today as 100 years ago. The entrepreneur may obtain capital and must be able to realize the means of production. The entrepreneur uses his intuition, is able to persevere resistance, have freedom from everyday activities and behold enough stamina to lead the innovation process. The entrepreneur must be able to imagine the possible results of the input factors.

Recent theories on entrepreneurship came from William Baumol (1968), with his statement that in order to encourage entrepreneurship, it is necessary to create conditions that allow the entrepreneurial pursuit of selfinterest to accord with social wealth creation. He also criticised entrepreneurship to be unproductive and even destructive in some societies, while it is productive in others.

Peter Drucker (1975) stated that an entrepreneur always searches for change, responds to it, and exploits it as an opportunity. Entrepreneurship is neither a science nor an art. It is a practice. Drucker considered the entrepreneur to be an unique agent of change and that successful innovation is a result of systematic hard work by the entrepreneur.

Bruce Kirchhoff (1989) presented an analysis where he gave the innovative entrepreneur a key role in capitalism and showed his importance in shaping the structure and growth rate of capitalist nations. In the dynamic process of new firm formation and growth, in his analysis called entrepreneurship, creates new owners and jobs and thereby creating and distribution of wealth. The economic system characterized by the process of wealth creation and distribution, is dynamic capitalism. With this analysis, he gave the innovative entrepreneur a key role in capitalism and explained the entrepreneur's importance in modern society.

Some of the different theories presented give the entrepreneur credibility as a catalyst for economic growth by being the leader of innovation.

Michael Young (1968) used the term social entrepreneur in literature in the 1960s and the 1970s, but it was when Bill Drayton used the term during the 1980s, that the term gained a worldwide spread, and was embraced 
by entrepreneurs in the US and U.K. According to Charles Leadbeater (1997), the value of social entrepreneurs comes in three main forms:

- In the short run, social entrepreneurs may bring measurable benefits to the wider economy by creating jobs, generating output or saving on public spending.

- In the medium run, they have great value as potential models for the reform of the welfare state, if they can work more productively in alliance with the public sector.

- Their more important long run contribution is their ability to create and invest social capital.

Values social entrepreneurs create in the economy is both monetary capital, but also social capital. The entrepreneurs are the actors that respond to opportunities, threats, uncertainties, constraints, and incentives emanating from the economic environment in which they operate. This puts social entrepreneurship together with entrepreneurship at the heart of economic growth and development.

\section{The Scandinavian welfare states}

Scandinavia consists of the social democratic countries Norway, Sweden and Denmark, where the government is strong and is trusted by the populations. The countries have developed a welfare system over the last 75 years, and at the same time, the political power has been centralised. The Scandinavian welfare model is one of several models that exist in the world today and was inspired by the British welfare model.

Lysestøl (2001) stated that there are two conditions that must be present for a state to be a welfare state. First, financial politics must be managed in such a way that economic fluctuations are avoided. Second, social politics that secure appropriate living conditions for the population.

The Scandinavian countries developed their welfare states gradually, and began with small and meanstested programs for limited groups in the society. It was during the socialist wave in the 1950s and 1960s that the Scandinavian welfare model was molded into the basis of what the welfare states in Scandinavia of today rest upon.

In contrasts to states such as USA and the UK the political debate is more adversarial and there is more open conflict, the Nordic countries have been described as consensual democracies where the political system has a high degree of legitimacy and support, where social diversions have been relatively mild, and where political deliberations aim to neutralize conflict and achieve compromise (Hilson, 2008, p. 26).

The Scandinavian welfare state is facing serious challenges. The challenges are related to legitimacy, governability, economic efficiency and scope of activity. The political, cultural and financial climate has changed considerably and the welfare state is not able to adapt to these changes in an adequate way.

State intervention in the private sector is extensive in Scandinavian countries. The state controls the market in several niches, it controls through grants and governmental funding, and the banking and financial system. The financial sector is market-driven, although the Scandinavian governments have embraced state capitalism with their high level of government owned companies that also distort the countries' economies. State capitalism challenges the free-market both conceptually and practically. 
The welfare state implies a social contract with the citizenry. It has now been one of the chief organizing principles of the lives of several generations and, hence, it represents a deeply institutionalized contract. Indeed, herein lies an obstacle to possibly any reform. As so much attitude research has shown, the welfare status quo remains very popular (Epsing-Andersen, 2002, p. 7).

Alliances between the state, large enterprises, and trade unions have created a highly regulated society with limited possibilities for individual initiatives. Entrepreneurship and social entrepreneurship are facing difficulties due to market situations that are similar to monopoly, systems that prevent entrepreneurs to compete on equal terms, and state owned companies that are difficult to compete with.

Social entrepreneurship is a recent term in Scandinavian countries and the field is diverse. Establishments from voluntary organizations to traditional enterprises call themselves social entrepreneurs. In most cases the organization, initiative, project, company or group is not a social entrepreneur but an enterprise with a social mission. Because many different activities are called social entrepreneurship, this leads to a dilution of the concept. It is important to distinguish social entrepreneurship from social service provision, corporate social responsibility (CSR) and social activism. A social entrepreneur is a changemaker in a welfare state and therefore can be regarded as a competitor, threat or critic of the welfare state and its institutions and governmental owned companies.

According to Petrella and Richez-Battesti (2014), the growing popularity of the social entrepreneurship notion therefore represents both a risk of dilution of third sector organisations among all forms of enterprises that make capitalism more human and an opportunity to innovate and build an alternative model. Indeed, if social entrepreneurship is seen as a private innovative solution to new societal challenges unmet by the state nor the market through an original way of combining resources, no alternative model is emerging. But, if social entrepreneurship is led by participative and democratic governance processes that imply a diversity of stakeholders and resources, it can be seen as a building block for an alternative model.

\section{The scientific approach to social entrepreneurship}

The highest and noblest form of freedom a human can experience is science. Science is produced by a single person in a process where human thought and reason is the source of truth and acknowledgment. Science is not labour, and not production in any form (Sandal, 2012, p. 168). While science is the stage before practice, research will always follow the practice. Research is to observe reality and explain it. Science is not knowledge, but science will eventually become knowledge. Science may lead to innovation. There are examples of people in history like: Einstein, Michelangelo and Schumpeter that show how free thought leads to free activity and creates big changes.

Since the beginning of the 1990s, research and the research community in the field has increased. With the number of published articles, number of scientists, an increased amount of journals and conferences focusing on innovation, entrepreneurship and social innovation has led to an opening of the field. To some extent, the community is still fragmented and the quality of research inconsistent. 
Research in the area of social entrepreneurship has to a significant degree been focused on retelling stories about successful company ventures based on concepts taken from organizational theory and the fields of behaviour and management, with emphasis on values such as leadership, stability, teaching, information and collaboration (Sandal, 2010, p. 12).

Mair and Martí (2006) stated that social entrepreneurship, as a practice and a field for scholarly investigation, provides a unique opportunity to challenge, question, and rethink concepts and assumptions from different fields of economy, management and business research. They continue their argument on the knowledge of social entrepreneurship can only be enhanced by the use of a variety of theoretical lenses and a combination of different research methods. They explain that social entrepreneurship has different facets and varies according to the socioeconomic and cultural environment. Insights from sociology, political science and organization theory will enrich theoretical understanding of social entrepreneurship. Innovations resulting from the continuous interaction between social entrepreneurs and the context in which they and their activities are embedded, may encourage relevant research and strengthen the understanding of social entrepreneurship and its ethical, social, financial and political significance.

\section{The practice of social entrepreneurship}

As the field of social entrepreneurship has grown and multiplied and wired itself together across the globe over the last 25 years, the rate of this plowing and seeding at the local level has accelerated dramatically (Drayton, 2006, p. 4). Leading social entrepreneurs are role models in the society and their contribution to recruit people to become changemakers are important, but they are few in numbers. Innovation carried through by leading social entrepreneurs overturn the existing pattern of local society. Innovations are accessible to all and attract followers and support in local communities and as such gain approval from neighbours, friends and family. Often a social entrepreneur has direct experience with the problem they want to solve and knows where the biggest challenges are in the sector, market and with the existing products or services.

Social entrepreneurs operate at the intersection of apparently contradictory parameters. They may bring change from the outside (exogenous), while at the same time they foster tendencies toward internal change (endogenous); their interventions seem sort of obvious and predestined (inevitability), although change may not have happened without people like them (contingency); they deal with people (methodological individualism) and at the same time they build new patterns, structures, laws, and symbols (sociological realism); finally, they are down to earth as they deal with concrete issues (realism), simultaneously influencing ideas, identification, and the level of hope (idealism); they bring direct, short-term solutions while at the same time aiming at far-reaching consequences, such as changing societal mindsets (Praszkier; Nowak, 2012, p. 48).

Social entrepreneurs have to be able to balance between different concepts and parameters such as innovation, social change, innovation management, idealism and capitalism. The ongoing development in the society and the changing field of social innovation demands considerable energy and mental effort from the 
social entrepreneur. Social entrepreneurs are accepted and supported by local communities, entrepreneurs and citizens because they create jobs and economic growth.

\section{Discussions}

Economic scientists were the first to explain and present the concept of entrepreneurship and its meaning in science, from Richard Cantillon to Peter Drucker and Bruce Kirchhoff. Different economic theories give the entrepreneur credibility as a leader of innovation and being a catalyst for economic growth. Schumpeter's theories on entrepreneurship and innovation are still valid in present time because an entrepreneur must master the same skills today. The entrepreneur's ability to combine land and labour in a way that previously was not possible or not as efficient as before, makes him a creative leader of the past, present and of the future.

Economic development and possibilities for the private sector is dynamic and always changing. Entrepreneurs serve a key mechanism to contribute to economic growth due to the knowledge created which can be commercialized in an enterprise. This is also valid for social entrepreneurs. Anyone can be a social entrepreneur and it is his ability to raise capital in order to spread new combinations of land and labor in a social system that is important. A social entrepreneur is a changemaker in a welfare state and the creative leader of innovation in a social system. Innovation is a creative process and relates to a financial system but is not dependent on it because the need for capital is limited. It is the entrepreneur's effort that is essential for the success or lack of it and the government can not control the outcome of an innovation process prompted by an entrepreneur in an open market. There are unlimited possibilities for social entrepreneurs in a changing global economy. To be a social entrepreneur cannot be inherited and anyone in the society can take that position. A social entrepreneur has the same opportunity to manage an innovation process as a commercial entrepreneur, because the social entrepreneur has to use his skills to plan, organize and coordinate himself to create the outcome he wants. Anyone can develop the skills needed.

Innovations are not dependent on the government, financial systems, capital, or political policies. Innovations have to adapt to changes in the economy when the innovation process has finished and the production function has been established. The ability to manage the activities is crucial for the entrepreneur in order to move an idea to realization. If the entrepreneur does not manage the innovation process, then the ideas will most likely not be fulfilled.

The welfare state is dependent on innovations to efficiently run their hospitals, military, public transport etc. The welfare state is a static system and can never innovate or be a social entrepreneur. In a free market an entrepreneur will only have competition from other entrepreneurs. In the Scandinavian welfare states, the political influence, the static condition of the system and hierarchy limit the emerging entrepreneurial economy. To lead innovation, take risks, and manage oneself is something many Scandinavians are not used to, but it's crucial for the success of the entrepreneur. The opportunity for a social entrepreneur is always present in all countries at all times. It is the entrepreneur's ability to respond to opportunities, threats, 
uncertainties, constraints, and incentives that creates new products, markets, organizations, methods of production or the conquest of new sources of raw materials.

In Scandinavian countries the state controls the market in several niches, it controls through grants and governmental funding, and the banking and financial system. The financial sector is market-driven, although the Scandinavian governments have embraced state capitalism with their high level of government owned companies that also distort the countries' economies. State capitalism challenges the free-market both conceptually and practically. Scandinavian governments have created a diversity of grants and funding programs where entrepreneurs can apply for capital. The funding comes with limitations for whom and what activities can get funding. In societies where power is highly monopolized, where free communication is guarded, or where there are no independent sources of money, entrepreneurship will be limited.

Entrepreneurship and social entrepreneurship are facing difficulties due to market situations that are similar to monopoly, or systems that prevent companies to compete on equal terms or state owned companies that are difficult to compete with. Even though the governments in the Scandinavian countries have stated that innovation and entrepreneurship is important and a prioritized field, there is a distance between visions and actions in governmental departments.

If research in the area of social entrepreneurship has been focused on retelling stories about successful company ventures based on concepts taken from organizational theory and the fields of behaviour and management, then science can be used as the source of truth and recognition.

When Sandal states that science is not labour, and not production in any form, science can then only be understood as a non financial activity. Science differs from both work and social innovation, because work and social innovation have the purpose of creating a service or a product. Science is the free thought and reason of a single human. Science is the stage before practice, and both science and research will give insights into social entrepreneurship and its significance in society.

The difficulty of reaching a consensus among scientists and researchers in the field of social entrepreneurship can be one of the reasons the definition and concept of social entrepreneurship is diluted.

In literature, social entrepreneurs are not considered to play a key role in a financial system. In practice, social entrepreneurs do not often reach large audiences and there is a need to increase impact across the globe to be considered an important part of the economy. Mair and Martí research into social entrepreneurship, shows that insights from sociology, political science and organization theory will enrich theoretical understanding of social entrepreneurship.

As Kirchhoff stated, there is a growing interest in dynamic modeling of capitalism. The importance of innovation in shaping the structure and growth rate of capitalist nations is massive. The entrepreneur plays a crucial role in modern society as a catalyst for economic growth. A society that does not encourage entrepreneurs and social entrepreneurs will not reap the benefits from the creativity and innovation process. Innovation carried through by social entrepreneurs overturn the existing pattern of local society and are accessible to all citizens. 


\section{CONCLUSION}

Different economic theories give the entrepreneur credibility as a leader of innovation and being a catalyst for economic growth. Schumpeter's theories on entrepreneurship and innovation are still valid in present time because an entrepreneur must master the same skills today. The entrepreneur's impact on the economy as a catalyst for growth and development of the society, is significant.

Creativity is necessary for a successful innovation: the creative individual, creative process, creative environment and creative product. An economy where economic performance is related to distributed innovation and the growth of innovative ventures is an entrepreneurial economy.

The understanding of social entrepreneurship is built upon science on entrepreneurship in the European tradition. With the lack of reaching a consensus among scientists and researchers in the field of social entrepreneurship, combined with many different activities called social entrepreneurship, this leads to a dilution of the concept.

The Scandinavian welfare state is a static system where political influence, the static condition of the system and hierarchy limit the emerging entrepreneurial economy. The welfare state is static and can never take the role of a social entrepreneur. To lead innovation, take risks, and manage oneself is something many Scandinavians are not used to, but it's crucial for the success of the entrepreneur. In the Scandinavian countries people are free to spend their time on what they want. The opportunity for a social entrepreneur is always present in all countries at all times.

The value social entrepreneurs create in a financial system is both monetary capital and social capital. The entrepreneurs are the actors that respond to opportunities, threats, uncertainties, constraints, and incentives emanating from the economic environment in which they operate. This puts social entrepreneurship at the heart of economic growth and development.

We need independent international science and theories for social entrepreneurs to access independent information and the source of truth and acknowledgment. As science is the stage before practice, it will give insights into social entrepreneurship and its significance in society.

A society that does not encourage entrepreneurs and social entrepreneurs will not reap the benefits from the creativity and innovation process. Innovation carried through by social entrepreneurs overturn the existing pattern of local society and are accessible to all citizens.

\section{Acknowledgements}

This scientific article was created at the Fil. Dr. Jan-U. Sandal Institute, Finstadjordet, Norway under the supervision of Prof. Fil. Dr. Jan-Urban Sandal, Executive Director and Owner at the Fil. Dr. Jan-U. Sandal Institute (Excellence in Science and Education). 


\section{Conflict of interests}

The author declare no conflict of interest.

\section{References}

Alestalo, M.; Kuhnle, S. (1987). The Scandinavian route: economic, social, and political developments in Denmark, Finland, Norway, and Sweden. International Journal of sociology, 16(03-04), 3-38.

Andersen, T. (2004). Challenges to the Scandinavian welfare model. European Journal of political economy, 20, 743754.

Baumol, W. J. (1968). Entrepreneurship in Economic Theory. American Economic Review, 58(2), 64-71.

Berkowitz, P. (1999). Virtue and the Making of Modern Liberalism. New Jersey, Princeton University Press.

Berman, S. (2006). The Primacy of Politics Social Democracy and the Making of Europe's Twentieth Century. Cambridge, Oxford University Press.

Briggs, A. (2001). Michael Young: Social Entrepreneur. New York, Palgrave Publishers Ltd.

Cantillon, R. (1755/2010). An Essay on Economic Theory. Alabama, Mises Institute.

Cornelius, B., Landström, H., \& Persson, O. (2006). Entrepreneurial studies: The dynamic research front of a developing social science. Entrepreneurship Theory and Practice, 30(3), 375-398.

Dees, J. G., \& Anderson, B. B. (2003). For-Profit Social Ventures, International Journal of Entrepreneurship Education, 2(1), 1-26.

Dees, J. G. (2012). A Tale of Two Cultures: Charity, Problem Solving, and the Future of Social Entrepreneurship, Journal of Business Ethics, 111(3).

Dees, J. G. (1998). Enterprising Nonprofits, Harvard Business Review, 76(1), 54-67.

Dees, J. G. (2007). Taking Social Entrepreneurship Seriously. Society, 44(3), 24-31.

Drayton, B. (2006). Everyone a changemaker. Social entrepreneurship's ultimate goal. MIT Press.

Drucker, P. F. (2006). Innovation and Entrepreneurship: Practice and Principles. New York, Harper Paperbacks.

Fayol, H. (1937). The administrative theory of the state. In L. H. Gulick \& L. F. Urwick (Eds.), Henri Fayol: Critical Evaluations in Business and Management, Volume 1 (101-114). Papers on the Science of Administration, Institute of Public Administration. London, Routledge.

Hilson, M. (2008). The Nordic Model: Scandinavia since 1945. London, Reaktion Books LTD.

Johannisson, B. (2004) Entrepreneurship in Scandinavia: Bridging Individualism and Collectivism. Crossroads of Entrepreneurship, 225-241.

Kirchhoff, B. A. (1989/1994). Entrepreneurship and Dynamic Capitalism: The Economics of Business Firm Formation and Growth. Westport, Greenwood Publishing Group.

Kuhnle, S., \& Hort, S. E. O. (2004). The Developmental Welfare State in Scandinavia, lessons for the developing world. Social policy and development, 1020-8208(17), 1-23.

Lie, E. (2012). Norwegian economic policies after 1905. Oslo, Universitetsforlaget.

Leadbeater, C. (1997). The Rise of the Social Entrepreneur. London, Demos.

Lysest $\varnothing 1$, P. (2002). The future of the welfare states. Nordic social work, (2), 102-106.

Mair, J., \& Martí, I. (2006). Social entrepreneurship research: A source of explanation, prediction, and delight. Journal of World Business, 41(1), 36-44.

Marglin, S. A., \& Schor, J. B. (1992). The golden age of capitalism, reinterpretation of the postwar experience. The Economic Journal, 102(412), 639-641.

Martin, R., \& Osberg, S. (2007). Social Entrepreneurship: The Case for Definition. Stanford Social Innovation Review, $5(28)$.

Petrella, F., \& Richez-Battesti, N. (2014). Social entrepreneur, social entrepreneurship and social enterprise: semantics and controversies. Journal of Innovation Economics \& Management, 2(14), 143-156. 
Rosenberg, N. (2004). Innovation and economic growth. Retrieved March 28, 2016, from https://www.oecd.org/cfe/tourism/34267902.pdf.

Say, J.-B. (1821/1971). A treatise on political economy. New York, Augustus M. Kelley Publishers.

Sandal, J.-U. (2010). Development in social entrepreneurship. Roskilde, Center for Socialt Entreprenørskab.

Sandal, J.-U. (2008) A Nordic perspective on social entrepreneurship. CSE Årsrapport, p. 113-127.

Sandal, J.-U. (2003). Searching for the Entrepreneur, can Joseph A Schumpeter's theories identify and differentiate entrepreneurs in the 20th Century? Stockholm, Almqvist and Wiksell International.

Sandal, J.-U. (2012). Work, innovation and the industriousness of life. Ekonomiska Samfundets Tidsskrift, 65(3), p. 157176.

Schumpeter, J. A. (1934/1978). The theory of economic development. New York: Oxford University Press.

Steyaert, C. (2000). Creating worlds: Political Agendas of Entrepreneurship. LOK Working Paper, (2).

Szirmai, A., Naudè, W., \& Goedhuys, M. (2011). Entrepreneurship, Innovation, and Economic Development. Maastricht, Oxford University Press.

Taylor, F. W. (1997). The principles of scientific management. New York, Dover Publications.

Thurik, A.R., Stam, E., \& Audretsc, D.B. (2013). The rise of the entrepreneurial economy and the future of dynamic capitalism. Technovation, 33 (8-9), 302-310.

Thurik, A.R., \& Audretsc, D.B. (2001). Linking entrepreneurship to growth. Small Business Economics, 13(1), 27-55.

Vike, H. (2002). The conscience of power, on political management and dilemma in The Welfare State. Oslo, Gyldendal forlag AS.

Weber, M. (1964). The Theory of Social and Economic Organisation. New York, Oxford University Press.

Young, M. (1968/1994). The Rise of the Meritocracy. Middlesex, Transaction Publishers.

About the author

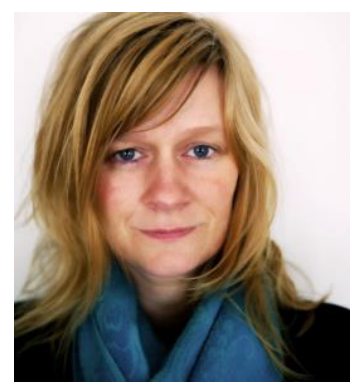

\section{Nadina Helen BAKOS}

Nadina Helen Bakos is an honorary research fellow at Fil. Dr. Jan-U. Sandal Institute, Norway. She has a B.A from Nordic Institute of Stage and Studio in Oslo. She presently focuses on Social entrepreneurship and the impact it has on the social sector, business, economic growth and citizens in the Scandinavian welfare states.

ORCID ID: $\underline{\text { https://orcid.org/0000-0002-8995-0218 }}$

Copyright (C) 2020 by author(s) and ACCESS Publishing Press This work is licensed under the Creative Commons Attribution International License (CC BY) 